\title{
Comparative Study of Emotional Competence among Teacher Trainees in Relation to Gender
}

\author{
Sona Thakur ${ }^{1}$, Dr. Jaya Chawla ${ }^{2}$ \\ ${ }^{1,2}$ Assistant Professor, Partap College of Education, Ludhiana (Punjab), India
}

\begin{abstract}
The present study explores that whether gender makes a difference on Emotional Competence of teacher trainees. A sample consisting of 200 teacher trainees was taken from the Colleges of Education of Ludhiana district. Data was collected with the help of Emotional Competence Scale (EC-Scale) by Sharma and Bharadwaj (2007). On statistical analysis, results clearly indicated that there exists no significant difference between male and female teacher trainees on the variable of Emotional Competence. The study will be of immense help to the teachers, parents and educational administrator and trainees. Because it will enable them to make arrangements for better environment for enhancing their competence which will in turn help the teacher trainees in their future life
\end{abstract}

Keywords: Emotional Competence, Gender, Teacher Trainees, Ludhiana

\section{Introduction}

Modern age is an age of technological advancement, rapid industrialization, urbanization and hard competition that has made an individual's life more confused and insecure. Excessive competition, rapidly changing cultural and social values, constant exposure to speed in every aspect of life has made the people in general and young generation in specific, live in urgency and emergency. In this competent world an individual's personality can function effectively if he is free from tensions, worries and emotional disturbances. According to Allport (1961) to achieve and maintain a feeling of adequacy, the individual has to acquire a few workable assumptions about the world where need for competence emerges as most fundamental motive of life. Because we survive through competence grow through competence and actualize ourselves through competence. The motivation towards competence is evident even in early playful and investigatory behaviour of children (White 1959) which they seek in social realm and as close as any other need (closer than sexual) to sum up the growth of the personality. A variety of factors such as intellectual, emotional and physical competencies play a part (Coleman 1970, Maslow 1970) to acquire skill and knowledge and the individual begins to develop two important virtues-method and competence in the congenial growth of personality.

\section{Emotional Competence}

Emotional Competence refers to one's ability to express or release one's inner feelings (emotions). It implies an ease around other and determines one's ability to successfully lead and express. It is described as the essential social skill to recognize, interpret and respond constructively to emotions in yourself and others. Emotional Competence can lead to improved health through avoiding stress that would otherwise result from suppressing emotions. It can also lead to improved relationship since inappropriate emotions are less likely to be expressed and appropriate behavior is not avoided through fear of triggering some emotion. The concept is distinct from emotional intelligence which while recognizing the importance of emotions gives emphasis to controlling or manipulating them. Emotional competence is made up of to words- "emotion" and "competence".
Emotions are root forces in the dynamics of human behavior and personality. Dictionary meaning of competence is doing well, where one can produce the type of effect, one desires. Competence refers to mastering of abilities to do a task and when ever this aspect of personality is related to emotions, it shall be deemed as Emotional Competence which happened to be efficiency that an individual acquire to deal with emotional situations affectively. According to Daniel Goleman (1998) for star performance in all jobs, in every field, Emotional Competence is twice as important as purily cognitive abilities for success at the highest levels, in leadership positions, emotional competence accounts for virtually the entire advantage. Emotional Competence enables the individual to cope with stressful life circumstances and find positive meaning in life.

\section{Review of Related Literature}

Lushch and Serpkence (1990) found that managers having self managements as a component of emotional competence have more profitable stores in sale. Barrack and Mound (1991) found that performance in all the jobs from top to bottom depends on emotional competence and mainly on its component consciousness. Castellan, Clifford and Kenchappanavar (2011) in their study indicated no significant influence of fathers' presence/absence on the Emotional Competence of adolescents. Also the presence and absence of the father had no significant influence on the gender in the sample. However there were variations on the five dimensions of emotional competence. Sidhu (2012) in her study revealed a significant relationship between emotional competence and mental health among adolescents.

\section{Need and Importance of the Study}

Education is the sheet anchor and cradle of the personality. The aim of education is not merely imparting bookish knowledge but to make youth good citizen by bringing about their physical mental, emotional and intellectual development. That's why it is an important function of education to make the students emotionally competent so that they may become well adjusted individuals. 


\section{International Journal of Science and Research (IJSR) \\ ISSN (Online): 2319-7064}

Index Copernicus Value (2013): 6.14 | Impact Factor (2014): 5.611

Over the years a growing interest has been manifested in the concept of emotional competence. An emotionally competent person is able to understand his emotional situation and mould his feeling according to the requirements of situation. Hence, emotional competence is quite important for a person to be successful in life. Many people though have a high abstract intelligence, are miserable failure in real life. The study will be of immense help to the teachers, parents and educational administrator and trainees. Because it will enable them to make arrangements for better environment for enhancing their competence which will in turn help the teacher trainees in their future life

\section{Operational Definition of the Term Used}

Emotional Competence- In the present study emotional competence refers to adequate depth of feeling, adequate expression and control of emotions, ability to function with emotions, ability to cope with problem emotions, enhancement of positive emotions as the dimensions of emotional competence as mentioned by Sharma and Bharadwaj (2007).

\section{Objectives of the Study}

1) To study Emotional Competence among teacher trainees.

2) To compare the Emotional Competence of male and female teacher trainees.

\section{Hypotheses}

There exists a significant difference between Emotional Competence of male and female teacher trainees.

\section{Delimitations of the Study}

1) The study was restricted to Ludhiana district only.

2) The study was limited to 200 teacher trainees only.

\section{Design of the Study}

As the present study is descriptive in nature therefore the descriptive and survey type method was employed. Significance of difference between means was worked out to know the difference between males and females regarding emotional competence of teacher trainees.

Sample of the Study: The data pertaining to Emotional Competence of 200 teacher trainees (100 male and 100 female) were collected.

\begin{tabular}{|c|c|c|c|c|}
\hline $\begin{array}{c}S . \\
\text { No }\end{array}$ & Name of College & Males & Females & Total \\
\hline 1 & $\begin{array}{c}\text { Partap College of Education, } \\
\text { Hambran Road Ludhiana }\end{array}$ & $\mathbf{5}$ & $\mathbf{2 0}$ & $\mathbf{2 5}$ \\
\hline 2 & $\begin{array}{c}\text { BCM College of Education, } \\
\text { Sector 32, Ludhiana }\end{array}$ & $\mathbf{5}$ & $\mathbf{2 0}$ & $\mathbf{2 5}$ \\
\hline 3 & $\begin{array}{c}\text { Malwa College of Education, } \\
\text { Civil Lines Ludhiana }\end{array}$ & $\mathbf{5}$ & $\mathbf{2 0}$ & $\mathbf{2 5}$ \\
\hline 4 & $\begin{array}{c}\text { G.M.T College of Education, } \\
\text { Jalandher Bypass Ludhiana }\end{array}$ & $\mathbf{5}$ & $\mathbf{2 0}$ & $\mathbf{2 5}$ \\
\hline 5 & $\begin{array}{c}\text { G.H.G College of Education, } \\
\text { Raikot Ludhiana }\end{array}$ & $\mathbf{5}$ & $\mathbf{2 0}$ & $\mathbf{2 5}$ \\
\hline 6 & $\begin{array}{c}\text { D. D.Jain College of Education, } \\
\text { Kidwai Nagar Ludhiana }\end{array}$ & $\mathbf{5}$ & $\mathbf{2 0}$ & $\mathbf{2 5}$ \\
\hline $\mathbf{7}$ & $\begin{array}{c}\text { A.S. College of Education, } \\
\text { Khanna, Ludhiana }\end{array}$ & $\mathbf{5}$ & $\mathbf{2 0}$ & $\mathbf{2 5}$ \\
\hline 8 & $\begin{array}{c}\text { G.H.G College of Education, } \\
\text { Gurusar Sudhar, Ludhiana }\end{array}$ & $\mathbf{5}$ & $\mathbf{2 0}$ & $\mathbf{2 5}$ \\
\hline & $\quad$ Total & $\mathbf{4 0}$ & $\mathbf{1 6 0}$ & $\mathbf{2 0 0}$ \\
\hline
\end{tabular}

\section{Result and Discussion}

In order to screen the data for meaningful purpose and to test the hypotheses, the data was analyzed with the help of various statistical techniques.

1) Description of the scores presented in terms of the frequency distribution, mean, S.D., skewness and kurtosis.

2) For comparison, t-ratio has been calculated.

Table 1: Showing Descriptive Statistics of scores of teacher trainees on the variable of Emotional competence $(\mathrm{N}=200)$

\begin{tabular}{|c|c|c|c|c|c|}
\hline Group & Mean & Median & S.D. & Skewness & Kurtosis \\
\hline Teacher trainees & 90.42 & 91.00 & 9.83 & -0.54 & 0.01 \\
\hline
\end{tabular}

The values of mean and median of the scores of the variable of Emotional Competence of teacher trainees as 90.42 and 91.00 respectively which are quite proximate to each other. The values of Skewness and Kurtosis in case of teacher trainees are -0.54 and 0.01 respectively showing the distribution as negatively skewed and leptokurtic. But these distortions are quite small. Therefore the distributions can be taken as normal. Frequency polygon of scores of teacher trainees on the variable of Emotional Competence is shown in Fig. 1 . 


\section{International Journal of Science and Research (IJSR) \\ ISSN (Online): 2319-7064}

Index Copernicus Value (2013): 6.14 | Impact Factor (2014): 5.611

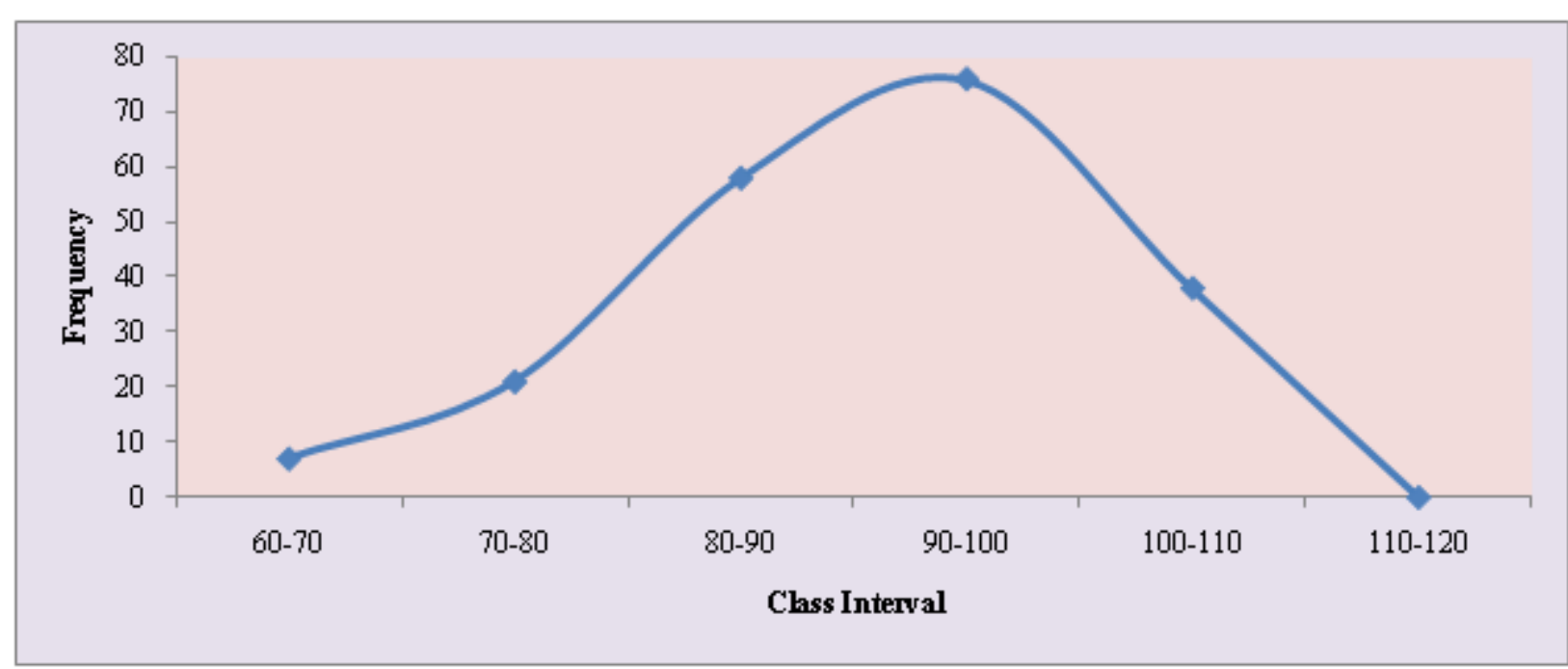

Figue 1: Frequency Polygon of scores of Teacher Trainees on the variable of Emotional Competence $(\mathrm{N}=200)$

Table 2: Descriptive statistics of scores of Male and Female Teacher Trainees on the variable of Emotional Competence

\begin{tabular}{|c|c|c|c|c|c|}
\multicolumn{7}{c|}{$(\mathrm{N}=200)$} \\
\hline Group & Mean & Median & S.D. & Skewness & Kurtosis \\
\hline Male & 92.48 & 94.00 & 9.07 & -1.31 & 1.48 \\
\hline Female & 89.90 & 91.00 & 9.97 & -0.39 & -0.23 \\
\hline
\end{tabular}

\section{Significance of Difference of Means}

To investigate the significance of difference between the means, if any, of Emotional Competence of teacher trainees in terms of their gender (male and female), the variables were assessed in terms of their scores in the test in these variables and t-test was employed.

Table 3: Significance of the Difference between Mean Scores of Emotional Competence of Male and Female Teacher Trainees $(\mathrm{N}=200)$

\begin{tabular}{|c|c|c|c|c|c|c|}
\hline S.No. & Group & $\mathrm{N}$ & $\mathrm{M}$ & $\mathrm{S} . \mathrm{D}$ & $\mathrm{SE}_{\mathrm{M}}$ & \multirow{2}{*}{ t-value } \\
\cline { 1 - 6 } 1. & Male & 40 & 92.48 & 9.07 & 1.43 & \multirow{2}{*}{1.49} \\
\hline 2. & Female & 160 & 89.90 & 9.97 & 0.79 & \\
\hline
\end{tabular}

Table III revealed that The mean scores of male and female teacher trainees on the variable of Emotional Competence are 92.48 and 89.90 respectively (as shown in Fig. 2). The tratio was calculated as 1.49 which is not significant at 0.05 level of confidence. This reveals that no significant difference exists between male and female teacher trainees on the variable of emotional competence.

Hence, the hypothesis 2 stating that there exists a significant difference between emotional competence of male and female teacher trainees is rejected.

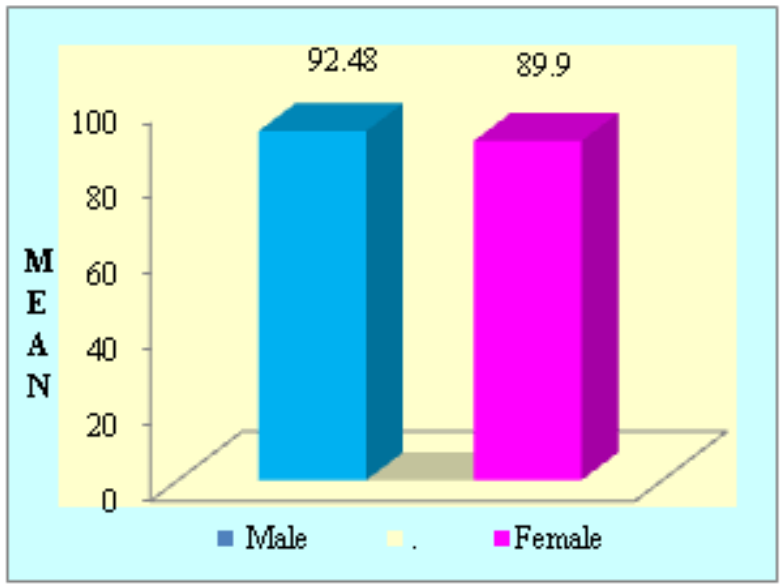

Figure 2: Bar Graph showing Difference of Mean Scores of Emotional Competence of Male and Female Teacher Trainees $(\mathrm{N}=200)$

\section{Educational Implications of the Study}

The present study reveals that to live in society, an individual should have to be emotionally competent. Tripathi (2012) in her study found a significant relationship between adjustment and emotional competence among college student. The study has great bearing for the teachers, administrators etc. In order to emotionalize a child, the teacher must be firstly emotional competent himself. For selecting teachers at two levels i.e. pre-training and preservice levels emotional competence of teachers can also be the criteria for selection, because the teacher who is himself emotionally competent can develop similar personalities. Denham (2001) found that emotional competence are a contributor to young children's social success. The study is also important for counsellors who can help individuals to understand themselves better, and enable them to deal with their strength and weaknesses and become an emotionally competence being.

\section{References}

[1] Allport, G.W. (1961). Patterns and growth in personality. New York: Holt Rhinehart and Winston. 


\section{International Journal of Science and Research (IJSR) \\ ISSN (Online): 2319-7064}

Index Copernicus Value (2013): 6.14 | Impact Factor (2014): 5.611

[2] Barrack, M. R., \& Mound, M.K. (1991). The big five personality and job performance. A meta analysis personal Psychology Journal of Community Guidance And Research 2 \& (3), 445-449.

[3] Castellon, C., \& Kenchappanavar R.N. (2011). Presence of father and the emotional competence of the adolescent in Goa, Journal Of Community Guidance And Research, 2\&(3), 445-449

[4] Coleman, J.C. (1970). Abnormal Psychology and Modern Life, Bombay : D.B Traraporevala Sons \& Co. Pvt. Ltd.

[5] Denham. (2001).Emotional Competence and successful management in self-awareness, emotional regulation, working co-operative and carrying about oneself and other. International Journal of Behavior Department, 25(4), 29-301.

[6] Goleman, D. (1998) Dictionary of Education,New York: Mc Graw Hill Book Company Inc.

[7] Lushch, R.F., \& Serpkence, R. (1990). Personal difference job tensions and star performance. A Study of Retail Mangers Journal of Marketing, 54 (1), 85-101.

[8] Maslow,A.H. (1970). Motivation \& personality $\left(2^{\text {nd }}\right.$ Ed.) New York: Hasper \& Row.

[9] Sharma, H.C., \& Bhardwaj, R.L (2007). Manual for the scale of Emotional Competence, Bal Niwas, Taj Basai Agra.

[10] Sidhu, R.K.(2012). A study of Emotional Competence of adolescents in relation to their Mental Health. The Sadbhavna -Research Journal of Human Development, 2(4), 61-68.

[11] Tripathi, D. (2012). Adjustment among college students in relation to Emotional Competence. Unpublished M.Ed. Dissertation; Panjab University, Chandigarh.

[12] White. R.W. (1959). Motivation Reconsidered: The concept of competence. Psychological Review; 66, 297833 